\title{
Cerita dari Timur Genre dan tema dalam Sastra Hindia-Belanda dari masa $\mathrm{VOC}^{1}$
}

\author{
CHRISTINA SUPRIHATIN
}

\begin{abstract}
ABSTR ACT
This article attempts to give a brief picture about the genre and themes in the Dutch-Indies Literature from the VOC period. During the VOC-period, more than six months was needed to embark on a journey by sea from the Netherlands to Batavia. Undertaking this journey meant encountering many obstacles which occurred through the work of man as well as nature. In addition, a successful landing on the shores of the East did not always ensure a friendly reception. Due to these obstacles which they encountered, only a small number of those who had set sail from Europe were able to return home safely. Most of those who managed to survive this long and dangerous journey to the land of spices, finally chose to stay and start a new life in the East. Some of these men, in an effort to establish their new life, were able to make contact and build relationships with the local women. This paved the way for the emergence of the Mestis culture, in which we find the elements of East and West.

KEYWORDS

Sastra Hindia-Belanda, VOC, genre, dan tema.
\end{abstract}

Pada tanggal 2 April 1595 tiga kapal dagang besar Belanda, Mauritius, Hollandia, dan Amsterdam meninggalkan pelabuhan Texel $^{2}$ menuju ke Timur: Hindia-Belanda. Sebuah kapal kecil Duyken ikut mengambil bagian dalam perjalanan panjang itu. Pertimbangan untuk melakukan pelayaran ke Timur itu antara lain dipicu oleh mahalnya harga rempah-

1 Makalah yang telah mengalami penyesuaian untuk pemuatannya dalam jurnal ini, sebelumnya disajikan dalam "Seminar Internasional Sastra dan Sejarah dalam Era VOC" yang diselenggarakan oleh Departemen Susastra dalam kerja samanya dengan Departemen Sejarah, Fakultas Ilmu Pengetahuan Budaya, Universitas Indonesia, pada tanggal 14 Januari 2008 di Depok.

2 Pelabuhan ini terletak di pulau Texel, salah satu dari jajaran pulau-pulau kecil di bagian utara negeri Belanda.

CHRISTINA SUPRIHATIN adalah pengajar Program Studi Belanda dan Departemen Susastra, Fakultas Ilmu Pengetahuan Budaya, Universitas Indonesia; mendapat gelar MA pada tahun 1991 dari Dutch Studies, Leiden University, Belanda, dengan pengutamaan Sastra HindiaBelanda. Saat ini penelitian utamanya tentang karya-karya penulis Indonesia yang termasuk dalam Sastra Hindia-Belanda. E-mail: chris@ui.edu. 
rempah di Eropa, sehingga muncul upaya untuk mendapatkannya dengan harga yang lebih murah - di daerah penghasilnya. ${ }^{3}$

Pada masa itu dibutuhkan waktu lebih dari enam bulan untuk menempuh perjalanan laut dari Negeri Belanda menuju Batavia. Banyak kendala yang menghadang perjalanan itu, baik yang disebabkan oleh faktor alam maupun manusia. Faktor alam seperti badai laut, kapal karam karena menabrak karang ataupun kapal terjebak di perairan dangkal. Kendala lain misalnya terjadi pemberontakan awak kapal, perompakan ataupun berjangkitnya penyakit-penyakit karena keadaan yang tidak higienis di kapal. Semua hal tersebut menjadikan perjalanan ke Timur bukanlah hal yang mudah dan menyenangkan.

Sesampainya di Timur mereka berhadapan dengan situasi dan penduduk pribumi yang asing, juga pesaing dari negara Eropa lainnya yang sering kali tidak ramah. Permasalahan tersebut semakin kompleks karena mereka harus beradaptasi dengan temperatur, gaya hidup yang berbeda, dan penyakitpenyakit tropis.

Masalah pelayaran dan situasi yang dihadapi membuat kecilnya jumlah awak kapal yang kembali dengan selamat di Eropa. Dari 240 awak yang pada tahun 1595 berlayar ke Timur, hanya 87 orang kembali ke Negeri Belanda pada tahun 1597. ${ }^{4}$ Angka tersebut tidak termasuk mereka yang memilih menetap di negeri yang baru. Pesona negeri yang sedemikian besar membuat mereka memutuskan untuk menetap dan memulai kehidupan baru di Timur. Sebagian dari mereka menjalin hubungan dengan wanita pribumi. Praktik hubungan campur antara pria Eropa dan wanita pribumi antara lain dipicu oleh sedikitnya jumlah wanita Eropa di Hindia-Belanda. Gubernur Jenderal Hindia-Belanda pada waktu itu, Jan Pieterzoon Coen (15871629), tidak mendapatkan izin dari pihak VOC untuk mendatangkan wanita totok ke Hindia-Belanda. Mahalnya biaya dan beratnya perjalanan yang harus ditempuh ke Hindia-Belanda merupakan dalih utama penolakan izin tersebut. Selain alasan ekonomis itu, wanita totok cenderung dianggap lemah dan terlalu banyak menuntut. Keadaan itu diperkirakan akan menyulitkan proses adaptasi dengan Hindia-Belanda dan dianggap dapat memicu tindak korupsi. Ditambah dengan kenyataan bahwa sebagian besar dari para wanita itu - setelah beberapa saat menetap di Hindia-Belanda - sering merasa tidak betah dan ingin kembali ke Belanda. ${ }^{5}$

Jumlah praktik hubungan campur pria Eropa dan wanita pribumi yang pada awalnya terjalin karena minimnya jumlah wanita Eropa di Hindia-Belanda, semakin meningkat dengan munculnya anggapan bahwa wanita lokal lebih kuat dibanding wanita Eropa. Wanita lokal menjadikan lelaki Belanda lebih mengenal negeri yang didatangi. Mereka juga lebih mengabdi dan tidak memiliki banyak tuntutan. Keberadaan mereka dianggap dapat meredam gejolak lelaki Belanda untuk kembali ke Eropa. Hal tersebut merupakan anggapan umum yang menjadi pembenaran atas 
keberadaan hubungan campur itu. ${ }^{6}$

Selanjutnya sebagai hasil hubungan campur itu hadir keturunan yang dianggap memiliki daya tahan yang lebih kuat - terutama dari segi fisik terhadap penyakit-penyakit daerah tropis. Dari keturunan tersebut lagi-lagi VOC masih mendapat keuntungan. Keturunan yang laki-laki bekerja untuk VOC dan yang perempuan menikah dengan lelaki Belanda yang bekerja untuk VOC. Demikianlah secara perlahan-lahan muncul budaya campuran yang terjadi karena peleburan elemen Barat dan Timur. ${ }^{7}$ Kehidupan di HindiaBelanda dan budaya campuran yang muncul tersebut sering menjadi topik pembahasan yang menarik dalam pelbagai tulisan.

Dalam artikel ini diberikan sedikit gambaran mengenai genre dan tema dalam Sastra Hindia-Belanda dari masa VOC. Tentu saja gambaran itu jauh dari lengkap mengingat masa keberadaan VOC di Hindia-Belanda meliputi rentang waktu yang panjang (1602-1799) dan karena banyaknya tulisan yang dihasilkan dari masa itu. Sehubungan dengan hal tersebut, artikel ini hanya membicarakan karya dari masa VOC di Hindia-Belanda, baik yang dipublikasikan di Belanda maupun di Hindia-Belanda. Seleksi juga dilakukan berdasarkan apresiasi para pemerhati Sastra Hindia-Belanda terhadap karyakarya dari masa VOC.

\section{VOC DALAM SASTRA: GENRE-GENRE PADA MASA VOC}

Singgungan budaya Barat (Belanda) dengan budaya lokal dari daerah yang menjadi koloni (Hindia-Belanda) dituangkan dalam berbagai karya. Nieuwenhuys (1978) mengkategorikan karya-karya tersebut sebagai IndischNederlandse Letterkunde, Sastra Hindia-Belanda. ${ }^{8}$ Menurut Paasman (1999), karya yang dapat dikategorikan sebagai Sastra Hindia-Belanda adalah semua teks ekspresif yang mempunyai keterkaitan erat dengan Hindia-Belanda.

Lebih lanjut, Paasman (2002) menguatkan pendapat Nieuwenhuys (1978) dan Beekman (1998) yang melihat bahwa Sastra Hindia-Belanda berakar dari 'catatan pribadi para pelaku pelayaran ke Timur' dan 'surat yang mereka kirim ke tanah air'. ${ }^{9}$ Paasman menggarisbawahi fungsi utama yang diemban oleh karya-karya pemula dalam ranah Sastra Hindia-Belanda itu, yaitu fungsi komunikasi. ${ }^{10}$ Fungsi ini, menurut Paasman, menjembatani daerah periferi (Hindia-Belanda dan teritori VOC lainnya) dengan daerah pusat (Belanda). Pendapat Paasman itu dapat dijelaskan dengan melihat jenis teks yang ditulis pada masa VOC. Dari teks-teks yang termarjinalkan yang sarat dengan ungkapan emosional yang berbentuk surat dan catatan harian, sampai teks-teks yang 'harus ditulis' karena tuntutan pekerjaan, misalnya jurnal dan

Van Zonneveld 1995: 3.

Van Zonneveld 1995: 3.

Nieuwenhuys 1978: 11-17. Pendapat Nieuwenhuys ini mendapat banyak tanggapan. Diskusi mengenai batasan dan kategori karya yang masuk ranah Sastra Hindia-Belanda dapat dilihat antara lain dalam Van Zonneveld (1995: ix-x), Boukema (1992: 1-19), dan Paasman (1999: 66-72, 2005: 163-195).

Paasman 1999: 66-67.

$10 \quad$ Paasman 2002: 33. 
laporan dari para pegawai. Di samping itu, juga ditemukan puisi puji-pujian dan cerita dengan pesan moral mengenai kehidupan di Hindia-Belanda. ${ }^{11}$

Menyoal jejak VOC dalam sastra ${ }^{12}$, Van Zonneveld menyatakan hanya ada sedikit genre yang terwakili. ${ }^{13} \mathrm{Jumlah}$ terbesar berupa catatan perjalanan. Pada mulanya catatan tersebut berbentuk jurnal kapten kapal. Catatan yang bersifat resmi itu berkembang menjadi penggambaran perjalanan yang terkadang dibumbui 'elemen fiktif'. Inilah cikal bakal subgenre cerita perjalanan. ${ }^{14}$

Selain catatan dan cerita perjalanan, kehidupan di daerah koloni juga dituangkan dalam bentuk teks lain. Seperti misalnya karya Nicolaus de Graaff, Reisen van Nicolaus de Graaff, na de vier gedeeltens des werelds [...] (1701), yang merupakan teks informatif mengenai kehidupan di Batavia pada waktu itu. Karya itu bisa dilihat sebagai 'Cermin Hindia-Belanda'. Karya pendeta François Valentijn yang berjudul Oud en Nieuw Oost-Indiën (1724-1726), 'Yang lama dan yang baru dari Hindia Timur', terdiri dari lima bagian dan tebalnya 5.144 halaman, juga memberikan informasi mengenai kehidupan di HindiaBelanda. $^{15}$

Pada masa VOC 'alam' belum dianggap sebagai elemen yang penting oleh banyak penulis. Meskipun demikian, ada beberapa karya dari masa VOC yang 'lebih maju dari karya semasanya', misalnya ketertarikan seorang pegawai VOC berkebangsaan Jerman, Georgius Everhardus Rumphius, akan keindahan alam Ambon dituangkan ke dalam berbagai tulisan, di antaranya D'Amboinsche Rariteitkamer [...] (1705). Dalam karya ini dipaparkan flora dan fauna yang ditemui Rumphius di lautan Ambon.

Ragam roman seperti yang dikenal dalam ranah Sastra Hindia-Belanda masa kini, misalnya mengenai permasalahan jati diri, belum ditulis pada masa VOC. Willem van Hogendorp pada tahun 1779 menulis sebuah novel tendensius ${ }^{16}$ yang berjudul Sophronisba (lihat Van Hogendorp 1921). Setahun kemudian terbit karya tendensius lainnya yang berjudul Kraspoekol.

Dalam genre puisi dari masa VOC dikenal tradisi lofdichten. Yang dimaksud dengan lofdichten adalah sajak-sajak yang mengagungkan kebesaran seseorang atau kemegahan suatu tempat. Batavia sebagai kota terpenting tempat VOC berkedudukan, pada tahun 1740 diolah oleh Jan Harmenz de Marre dalam Batavia, begrepen in zes boeken, 'Batavia, dalam enam buku'. Selain sajak pujian ditemukan juga berbagai sajak yang mengusung nilai-nilai moral, seperti karya Matthijs Cramer D'Indiaensche Tyfferboom (1670), 'Pohon Tyffer Hindia-Belanda'. Pohon sejenis palem ini dapat disadap dan diolah menjadi minuman beralkohol yang sangat disukai oleh penduduk pribumi. Cramer membandingkan air sadapan pohon itu dengan air yang berasal dari

11 Paasman 2002: 37.

12 Dalam hal ini sastra diartikan seperti yang dimaksud oleh Nieuwenhuys (1978). Buku Nieuwenhuys ini dalam ranah Sastra Hindia-Belanda dianggap sebagai buku referensi utama.

Van Zonneveld 1995: 10.

Van Zonneveld 1995: 3.

Nieuwenhuys 1978: 50.

16 Novel tendensius menggiring pembaca ke suatu permasalahan dan memberikan pemecahan permasalahan tersebut. 
Tuhan. Sebagian besar sajak dalam kumpulan sajak itu menyoroti moralitas di Hindia-Belanda. ${ }^{17}$

Menurut Paasman (1991) pada masa VOC lagu-lagu menjadi pilihan untuk membakar semangat orang untuk ikut berlayar ke Hindia-Belanda. Melalui berbagai lagu citra positif Hindia-Belanda dibangun. HindiaBelanda digambarkan sebagai negeri yang indah tempat orang mudah meraup kekayaan. Wie wil d'r mee naar Oost-Indië varen? ... Daar kunt gij veel geld en goed vergaren, 'Siapa ingin ikut berlayar ke Hindia-Belanda? Di sana orang mudah mengumpulkan uang dan benda berharga'. Demikian bunyi sepenggal lagu dari masa VOC. Lagu-lagu berisi bujuk dan rayuan semacam itu didendangkan dalam berbagai kesempatan di banyak tempat, seperti di pasar, tempat-tempat minum, dan di pesta perkawinan. ${ }^{18}$

\section{DARI IMPIAN MENUJU KENYATAAN: TEMA DALAM BERBAGAI GENRE Genre prosa}

Teks-teks yang termasuk dalam genre prosa pada masa VOC dibedakan menjadi tiga jenis. Pertama, teks yang dikelompokkan menjadi 'sastra perjalanan', yaitu jurnal, catatan, dan cerita perjalanan. ${ }^{19}$ Kedua, teks informatif mengenai keadaan di Hindia-Belanda. Ketiga, teks berupa novel, cerita-cerita pendek, dan roman.

\section{Sastra perjalanan}

Banyaknya bentuk sastra perjalanan yang ditemukan pada masa VOC tidak dapat dilepaskan dari kebijakan VOC. Para perwira dan pegawai VOC - dalam skala kepangkatan tertentu - diwajibkan membuat laporan, yang dikenal dengan scheepsjournaal, 'jurnal kapal'. Para awak kapal - kapten, juru mudi, tenaga paramedis, dan berbagai jenis fungsi pekerjaan lain - mencatat dengan teliti hal-hal yang dihadapi selama perjalanan. Hal teknis seperti arah datang angin selama pelayaran, kerusakan kapal karena badai dan kejadian yang tidak diharapkan seperti kericuhan antar awak kapal dan awak kapal yang sakit dan meninggal. Juga hal-hal yang terkait dengan penerapan peraturan pelayaran, seperti sanksi terhadap pelanggaran awak kapal. Jenis-jenis kapal lain yang berpapasan dengan kapal VOC juga dilaporkan. Tentu saja laporan itu dibuat semata-mata untuk kepentingan VOC dan tidak dimaksudkan untuk konsumsi publik. ${ }^{20}$

Selain laporan 'wajib' tersebut, tidak jarang para awak kapal membuat catatan pribadi sebagai wadah pencurahan perasaan. Dari catatan yang bersifat pribadi ditemukan kejadian-kejadian yang luar biasa, seperti yang digambarkan oleh Willem Ysbranstsz. Bontekoe van Hoorn (1587-1657) dalam Journael ofte Gedenckwaerdighe beschrivinghe van de Ost-Indische Reyse (1646), 'Jurnal perjalanan ke Hindia-Timur'. Boukema (1992) mencatat jurnal itu sebagai karya yang menduduki urutan pertama dalam Sepuluh besar karya

17 Paasman 2002: 53.

18 Paasman 1991: 3.

19 Istilah yang digunakan Paasman (2002) yang mengelompokkan jurnal, catatan, dan cerita perjalanan sebagai 'sastra perjalanan' (reisliteratuur).

20 Paasman 2002: 67. 
paling ternama dalam ranah Sastra Hindia-Belanda. ${ }^{21}$ Dalam salah satu bagian jurnal kapten Bontekoe diceritakan bahwa dia menjadi saksi hidup ketika kapal yang dinahkodainya meledak di Selat Sunda. Fragmen kecelakaan itu paling sering dikutip dalam berbagai tulisan mengenai cerita perjalanan dari masa VOC. ${ }^{22}$ Kecelakaan itu memakan lebih dari 150 jiwa, dan saat itu Bontekoe - terkenal sebagai nakhoda yang religius - terlempar ke udara. Diceritakan bahwa pada saat yang kritis itu Bontekoe menengadah ke langit dan berdoa, memohon pengampunan dan keselamatan. Tuhan mendengar dan mengabulkan permohonan nahkoda yang saleh itu. Paasman (2002) melihat adanya kesamaan kejadian penyelamatan semacam itu dalam legendalegenda di Abad Pertengahan.

Benteng-benteng pertahanan VOC biasanya dibangun dekat pesisir. Hampir-hampir tidak ditemukan catatan yang menuturkan keadaan daerah pedalaman yang letaknya jauh dari benteng VOC. Karya Rijklof van Goens, Javaense Reyse (1666), 'Perjalanan di Jawa', menarik untuk dicantumkan karena menceritakan pengalaman perjalanan Van Goens dari Semarang menuju ibukota kerajaan Mataram (lihat H.J. de Graaf 1956). Berbeda dari karya penulis sastra perjalanan dari masa itu, Van Goens memasukkan sejumlah besar penggambaran alam. Kekagumannya akan keindahan alam Jawa diungkapkan dengan sentuhan pribadi. ${ }^{23}$ Gunung Merbabu digambarkan memiliki pemandangan terindah di dunia, air terjun digambarkan amat jernih, dan penduduk di kaki gunung diceritakan sangat ramah. Selain pemandangan alam yang mempesona, Van Goens juga mengungkap faktafakta yang menakjubkan dari balik dinding Kraton Mataram. Raja Mataram digambarkan sebagai pribadi yang hanya tiga kali seminggu muncul di depan umum. Raja dikelilingi wanita, dengan empat istri resmi dan sekitar 50 selir. Keselamatan Raja dijaga antara lain oleh sekelompok punggawa yang terdiri dari lima puluh perawan, dibantu sekitar 3.000 wanita paruh baya. Raja dan selir-selirnya dilayani oleh 6.000 wanita. $^{24}$

Karya prosa berisi gambaran dan informasi mengenai keadaan di Hindia-Belanda Karya Nicolaus de Graaff (1701) diterbitkan setelah kematiannya. Buku ini menyoroti kehidupan orang Eropa dan Indo Eropa yang tinggal di Batavia. De Graaff memaparkan berbagai sisi kehidupan seperti wanita di masa itu, perbudakan, dan tentang pegawai VOC. Wanita, di masa itu, dikelompokkan menjadi beberapa golongan berdasarkan asal-usulnya: (1) wanita kulit putih lahir di Eropa, (2) wanita kulit putih lahir di Hindia-Belanda, (3) wanita berdarah campuran, dan (4) wanita pribumi berkulit hitam. Selanjutnya yang berdarah campuran dipilah lagi menjadi: (1) Mestiso, berasal dari bapak Eropa dan ibu Pribumi, (2) Kastiso, berasal dari bapak Eropa dan ibu Mestiso. ${ }^{25}$

Wanita yang telah dikelompokkan ini semuanya mendapat karakter negatif. Wanita dicitrakan sebagai sosok yang sombong, malas, penuh nafsu,

$21 \quad$ Boukema 1992: 19.

22 Van Zonneveld 1995: 4.

23 Nieuwenhuys 1978: 25-26.

24 Van Zonneveld 1995: 6.

25 Paasman 2002: 71-72. 
dan kejam. Wanita yang tinggal di daerah tropis itu, menurut De Graaff, cenderung 'lemah' dalam banyak sisi kehidupan, tetapi tidak dalam masalah seksual. Mereka malas dan menyerahkan semua urusan rumah tangga - juga pendidikan anak - kepada para budak atau pembantu mereka. Para wanita digambarkan memperlakukan para budak dan pembantunya tidak manusiawi. Kekerasan verbal sering dilakukan dan tidak jarang diikuti dengan kekerasan fisik. Citraan wanita yang negatif tersebut terus melekat pada banyak tokoh wanita dalam roman dan cerita Sastra Hindia-Belanda. ${ }^{26}$

Gambaran negatif juga lekat pada para pegawai VOC. Mereka disebut De Graaff sebagai kelompok koruptor. Citra buruk ini tidak lepas dari motivasi mereka pergi ke Timur. Hanya sebagian kecil dari pegawai VOC memiliki ketertarikan terhadap negara dan bangsa yang didatanginya, selebihnya memiliki motivasi finansial. Praktik korupsi dan nepotisme di zaman VOC diungkap De Graaff dengan lugas. Karya De Graaff yang sarat membongkar borok masa itu, untuk waktu yang lama menjadi sumber penting bagi banyak penulis sastra perjalanan. ${ }^{27}$

Karya besar lain yang layak disebutkan, ditulis oleh pendeta François Valentijn. Nieuwenhuys menyebutkan bahwa karya itu terdiri dari lima bagian. Bagian pertama dan kedua dicetak pada tahun 1724. Tiga bagian lainnya menyusul dalam selang waktu beberapa tahun. Sebuah mahakarya yang dicetak dalam format folio, berilustrasi, dan dilengkapi dengan peta. ${ }^{28}$ Paasman (2002) menyebutkan bahwa karya itu tidak terdiri dari lima bagian, seperti yang dicantumkan dalam buku Nieuwenhuys (1978), tetapi hanya tiga bagian saja. ${ }^{29}$ Karya Valentijn sampai saat ini masih saja dirujuk, dipelajari, dan dibicarakan. Sebuah karya yang sarat dengan berbagai informasi dari berbagai bidang ilmu: sejarah, flora, fauna, budaya, dan masyarakat lokal. Dalam karya itu penduduk pribumi dikelompokkan berdasarkan warna kulit. Semakin terang warna kulit seseorang semakin tinggi nilainya. Suatu pendapat yang menarik, karena stereotipe penduduk yang sampai saat ini masih hadir dalam berbagai karya Sastra Hindia-Belanda, telah disinggung oleh Valentijn di masa VOC. Paasman (2002) dan Beekman (1998) memberikan apresiasi yang tinggi terhadap gaya penceritaan Valentijn. Valentijn menghadirkan unsur humor dan cenderung anekdotis saat menuturkan kejadian yang dialaminya sendiri ataupun yang diceritakan orang kepadanya. ${ }^{30}$

Penghargaan tinggi juga layak diberikan kepada karya Rumphius. Seperti telah disebutkan sebelumnya, bertahun-tahun lamanya Rumphius berdinas di Ambon dan keelokan flora dan fauna wilayah tersebut menarik perhatiannya. Semasa berdinas dia membuat catatan lengkap tentang tanaman dan binatang yang ditemuinya. Saat berusia tiga puluh dua tahun dia menjadi buta, tetapi tidak menghalanginya untuk melanjutkan pengamatannya dengan bantuan asisten dan anaknya. Menimbang nilai catatan Rumphius,

\footnotetext{
26 Paasman 2002: 72.

27 Paasman 2002: 74.

28 Nieuwenhuys 1978: 49-50.

29 Paasman 2002: 81.

30 Paasman 2002: 81.
} 
VOC tetap mempekerjakannya. Untuk membantu penyelesaian tulisannya, VOC mengirimkan asisten yang menolongnya mencatat dan melukiskan objek pengamatannya. Sampai akhir hayatnya (1702) Rumphius tinggal di Ambon. Dia menggambarkan alam dengan sepenuh hati, tidak sebagai objek semata. Karyanya mencerminkan kecintaan yang besar terhadap alam, yang diungkapkan dalam bahasa yang lembut. Ungkapan kekagumannya juga lahir dalam bentuk sajak. Dia mencitrakan kemolekan flora bawah air Ambon seperti taman milik Thetis, sang dewi laut. ${ }^{31}$ Puluhan tahun setelah kematiannya, Het Amboinsche kruid-boek (1741-1750), buku yang menceritakan 'rempah-rempah Ambon', diterbitkan.

\section{Roman dan cerita-cerita pendek}

Pada masa VOC tidak banyak dihasilkan roman dan cerita-cerita pendek. Karya Johan van Heemskerck yang berjudul Batavische arcadia (1637) menceritakan perjalanan sekelompok wanita dan pria penduduk kota Den Haag menyusuri beberapa kota sekitar Den Haag. Setibanya di Katwijk, tema pembicaraan adalah mengenai hal-hal mistis. Salah satu anggota kelompok itu menyatakan bahwa hal-hal mistis itu tidak nyata dan sebagai contoh dia menceritakan sebuah kejadian di Hindia-Belanda ketika seorang penyihir pribumi bertugas menangkap buaya. Penyihir itu membutuhkan sembilan hari untuk menangkap dan menyerahkan buaya kepada GubernurJenderal. Setelah waktu yang ditentukan, penyihir menyerahkan buaya yang ditangkapnya hidup-hidup. Gubernur-Jenderal yang mengirim orang untuk mengikuti cara kerja penyihir itu, menemukan bahwa bukan hal yang bersifat magis yang digunakan penyihir untuk menangkap buaya itu. Penyihir menggunakan seekor kera yang diikatkan pada sebuah kait bertali. Saat buaya menyantap kera, kait pun ikut tertelan. Setiap kali tali berkait itu ditarik, buaya merasa sakit dan dia akan mengikuti arah tarikan tali. Anekdot yang lucu itu diceritakan oleh Van Heemskerk itu, merupakan contoh dari 'hal mistis' yang ternyata tidak supranatural. Paasman (2002) menjelaskan bahwa karya Van Heemskerck itu telah memperkenalkan salah satu motif penting yang kemudian kerap diolah dalam roman Sastra Hindia-Belanda, yaitu stille kracht, kekuatan supranatural. ${ }^{32}$

Pemikiran rasional dari abad kedelapan belas juga mempengaruhi Hindia-Belanda. W. van Hogendorp (1779, lihat 1921) mendedikasikan tulisannya untuk para ibu yang ada di Batavia pada masa itu. Van Hogendorp menghimbau para ibu membaca karyanya demi kesejahteraan anak-anak mereka. Novel itu bertutur tentang kebahagiaan seorang ibu yang anaknya selamat dari epidemi cacar yang melanda Batavia, karena sebelumnya sang ibu mengizinkan anaknya divaksinasi. Pemikiran khas abad kedelapan belas kentara hadir dalam novel tersebut, ada imbalan untuk sikap bijak dan ada hukuman untuk yang berpandangan sempit. Karya itu memberi dampak pada masyarakat Batavia waktu itu, banyak orang tua setelah membaca karya itu memvaksinasi anak-anaknya. ${ }^{33}$

31 Paasman 2002: 81.

32 Paasman 2002: 83.

33 Nieuwenhuys 1978: 68. 
Karya Willem van Hogendorp (1780) memperlihatkan buruknya perlakuan terhadap kaum budak. Kraspoekoel adalah majikan bertangan besi yang pada akhirnya tewas di ujung keris salah satu budak yang memberontak. Nieuwenhuys (1978) berpendapat bahwa Van Hogendorp dengan dua karyanya tersebut menyoroti permasalahan yang ada di masa itu - vaksinasi dan perbudakan. Novel karyanya merupakan semacam model. Dua puluh tahun setelah novel itu diterbitkan, Dirk van Hogendorp, anak Willem van Hogendorp menggubah novel itu menjadi sebuah lakon drama. Dalam kemasan terakhir ini, pesan W. van Hogendorp - anti perbudakan dan perdagangan manusia - jauh lebih ditonjolkan. ${ }^{34}$

\section{Genre puisi}

Dalam genre ini ditemukan dua jenis sajak, yaitu sajak puji-pujian dan sajak yang berisi pesan moral.

Kemegahan Batavia sebagai pusat kedudukan VOC diangkat oleh Jan Harmenz de Marre (1740). Isi karyanya ini didasarkan pada pengalamannya selama kurang lebih dua puluh tahun lamanya bekerja untuk VOC dan tinggal di Batavia. ${ }^{35}$ Buku pertama berisi sajak-sajak yang memuji kebesaran VOC yang digambarkan sebagai Ratu dari Timur yang berhasil membawa pundi-pundi uang ke Barat dan telah membesarkan kota Batavia. Buku kedua berisi sajak-sajak tentang perjalanan mengunjungi bangunan-bangunan VOC yang megah di Batavia Timur dan makam orang-orang yang telah berjasa bagi VOC. Buku ketiga berisi sajak-sajak yang menceritakan mimpi penyair bertemu dengan J.P. Coen yang menuturkan asal mula kota Batavia. Buku keempat berisi kunjungan ke Batavia Barat. Di bagian barat itu terdapat gudang-gudang milik VOC, pasar ikan, dermaga tempat kapal VOC berlabuh, panti asuhan dan rumah sakit untuk orang Cina. Bagian barat Batavia itu dipenuhi orang asing dan penduduk pribumi. Buku kelima memuat sajaksajak tentang kebesaran VOC dan keberadaan benteng VOC di wilayah Asia. Dari benteng-benteng tersebut berlayar kapal VOC dengan berbagai muatan. Sajak-sajak tentang Jawa dimuat dalam buku keenam. ${ }^{36}$

Lewat sajaknya De Marre meramalkan bahwa Batavia akan selalu terkenal, sebagai kota besar milik Belanda di seberang lautan, tempat berbagai bangsa dari Asia melebur. ${ }^{37}$

Sajak-sajak yang mengusung nilai moral ditemukan dalam karya Matthijs Cramer (1670). Karya itu berbentuk kumpulan emblemata - puisi pendek penuh dengan simbol - yang diberi penomoran dan dimulai dengan moto. Flora dan fauna serta tata susila Hindia-Belanda dihadirkan dalam sajak. Cramer dengan tajam dan bernada satiris menyoroti sikap sombong, sifat suka bergunjing, kebiasaan berjudi, mabuk-mabukan, menipu, munafik, dan berselingkuh. Menurut Cramer seharusnya orang-orang Kristen berkulit putih itu memberikan contoh yang baik kepada penduduk asli. Motif-motif tersebut sampai abad kedua puluh masih ditemukan dalam berbagai karya

\footnotetext{
$34 \quad$ Nieuwenhuys 1978: 68-72.

35 Van Zonneveld 1995: 9 dan Paasman 2002: 48.

36 Paasman 2002: 48-49.

37 Paasman 2002: 50.
} 
Sastra Hindia-Belanda. ${ }^{38}$

Pembunuhan orang-orang Cina di Batavia pada tahun 1740 menjadi inspirasi bagi Willem van Haren dalam menulis karyanya (1742). Dari Belanda Van Haren memprotes pembunuhan itu melalui kumpulan sajaknya yang diterbitkan dua tahun setelah pembantaian etnis tersebut. Gerrit Verbeet, yang bekerja untuk VOC dan menjadi saksi mata kekejian itu, menuangkan kejadian tersebut dalam sajak "Zeegezang" (1752). Kedua karya itu memperlihatkan dengan jelas kritik terhadap praktik kekerasan sebagai dampak dari keputusan para pembesar VOC yang menduga orang-orang Cina akan memberontak. Ketakutan dan rasa benci terhadap kelompok etnis itu menjadi pemicu pembunuhan orang-orang Cina di Batavia. Sekitar 10.000 orang mati, termasuk wanita dan anak-anak yang tidak berdosa, banyak rumah dibakar dan harta benda mereka dijarah. ${ }^{39}$

Puisi di masa VOC seringkali terkait dengan 'kejadian khusus'. Sajak-sajak ditulis karena ada kejadian luar biasa dalam kehidupan seseorang. Jacob Steendam, penyair yang sangat mengagumi kebesaran VOC, mengelu-elukan kemenangan VOC atas Makassar dalam sajak "Dank-offer" (1669). Sajak itu merupakan ungkapan rasa syukur kepada Tuhan karena Belanda telah lepas dari belenggu penjajahan Spanyol, ditunjukkan jalan menuju Batavia dan berhasil mendirikan kota Batavia. ${ }^{40}$

Laurens van Elstland, penyair semasa Steendam, menulis sajak terkait dengan pengangkatan Cornelis Speelman menjadi Gubernur Jenderal pada tahun 1681 (lihat Paasman 2002). ${ }^{41}$ Dia juga menulis sajak dalam rangka pameran yang mempertontonkan penggalan kepala seorang kapten Ambon, Joncker Manipa Saweru (1689), yang tewas saat pemberontakan melawan VOC. Kebesaran VOC dielu-elukan karena berhasil menumpas pemberontakan Saweru dan membawa keamanan di Ambon. ${ }^{42}$

\section{Lagu}

Pada masa VOC tidak dapat dipungkiri bahwa lagu berperan penting untuk menuturkan keadaan saat itu. Bagi mereka yang buta huruf atau yang tidak memiliki akses untuk membaca jurnal atau cerita perjalanan, dapat memperoleh informasi mengenai negeri penghasil rempah dari berbagai lagu yang dinyanyikan di banyak kesempatan. Lagu-lagu itu berisi informasi, misalnya tentang perjalanan ke Timur, kehidupan di negeri tropis, dan perjalanan pulang ke tanah air. Lagu-lagu tersebut diperdengarkan dalam acara yang banyak dihadiri orang, seperti pesta pernikahan, pasar, dan pasar malam. Biasanya lagu semacam itu tidak sulit dinyanyikan karena mengikuti melodi lagu rakyat yang populer dengan lirik yang mudah dihafal dan irama menarik dan mudah diingat. ${ }^{43}$

\footnotetext{
38 Van Zonneveld 1995: 9 dan Paasman 2002: 52-54.

39 Paasman 2002: 57.

40 Paasman 2002: 58-59.

41 Tentang Elstland, dikutip oleh Paasman (2002) dari Karel Bostoen (1988: 185-211).

42 Paasman 2002: 59-60.

43 Paasman 1991: 150, 2002: 62.
} 
Kontribusi lagu tersebut dalam membangun citraan Hindia-Belanda yang positif, jelas terlihat. Hindia-Belanda digambarkan sebagai luilekkerland, negeri tempat orang dengan mudah meraup kekayaan karena tanahnya mengandung banyak emas dan batu permata, kaya rempah-rempah, memiliki makanan yang lezat, serta wanita-wanita menarik. ${ }^{44}$ Cerita tentang HindiaBelanda itu berhasil menarik minat banyak orang sehingga mereka akhirnya ikut berlayar dengan kapal VOC. Setengah dari mereka yang mendaftarkan diri berasal dari negara-negara di Eropa: Skandinavia, Perancis, Italia, dan terutama dari Jerman. Tidak jarang orang-orang itu berasal dari kalangan 'bermasalah', seperti tunakarya, pemabuk, penjudi. Mereka juga tidak memiliki keterampilan berlayar, dan kondisi fisik mereka sering kali tidak prima. ${ }^{45}$

Beberapa lagu dari masa VOC mengalami adaptasi dan bahkan masih dinyanyikan berabad-abad setelah keruntuhan VOC (1799). Lagu-lagu tersebut diperkenalkan kepada khalayak ramai baik secara lisan maupun tertulis. Sebagian dari lagu-lagu itu terbit dalam bentuk buku, tetapi biasanya penciptanya tidak diketahui. ${ }^{46}$

Selain lagu-lagu yang bersifat mempropagandakan keuntungan berlayar dengan kapal VOC ke Timur, juga ditemukan lagu-lagu yang membawa pesan moral. Lirik lagu semacam itu menuturkan betapa beratnya risiko pelayaran ke Hindia-Belanda dan betapa berbahayanya kehidupan di Hindia-Belanda. ${ }^{47}$

\section{PENUTUP}

Pada masa VOC keberagaman karya yang dihasilkan masih terbatas. Yang terutama ditemukan adalah karya-karya yang masuk dalam subgenre sastra perjalanan yang bertema bahaya pelayaran ke Hindia-Belanda. Dalam genre prosa, bentuk tulisan bersifat ilmiah-populer menjadi pilihan: sejumlah karya menawarkan informasi mengenai flora, fauna, adat-istiadat, dan tradisi. Dalam genre puisi, tidak dikenal mahakarya dari masa VOC. Apabila teks-teks lagu dapat dianggap sebagai bagian dari genre ini, maka lagu-lagu itu dapat dianggap paling berperan dalam pembentukan citraan Hindia-Belanda.

Semua karya yang ditulis dari masa VOC, kehidupan di daerah koloni dipandang dari kacamata penulis yang berasal dari negeri Belanda. Gambaran dan perhatian kepada masyarakat lokal masih samar dan tidak lengkap. Perhatian yang diberikan terbatas pada wanita lokal. Itu pun hanya terkait dengan aspek-aspek tertentu, misalnya hubungan wanita pribumi dengan pria Eropa, atau wanita dalam posisinya sebagai budak atau pembantu. Meski perhatian tidak dicurahkan pada masyarakat pribumi, ditemukan juga karya yang menceritakan keadaan alam Hindia-Belanda.

Dengan segala keterbatasan yang dimunculkan dalam berbagai karya dari masa VOC, hal yang menarik adalah bahwa beberapa pandangan yang ditemukan dalam karya dari masa VOC dapat dianggap 'modern' dan tidak

\footnotetext{
$44 \quad$ Van Zonneveld 1995: 9.

$45 \quad$ Paasman 1991: 151.

46 Paasman 2002: 62.

47 Van Zonneveld 1995: 9-10.
} 
usang dimakan zaman. Misalnya dari masa VOC itu sudah diangkat masalah penindasan sesama yang diwujudkan dalam bentuk kekerasan terhadap para budak. Atau tentang kriteria keindahan yang semata-mata dilekatkan pada hal-hal yang bersifat fisik, seperti kecantikan wanita didasarkan atas warna kulit.

\section{DAFTAR PUSTAKA}

Beekman. E.M. 1998. Paradijzen van weleer; Koloniale literatuur uit NederlandsIndië. Amsterdam: Prometheus.

Boukema, H.J. 1992. "Indisch-Nederlandse letterkunde", Neerlandica Extra Muros XXX-1 (Februari): 1-19.

Cramer, Matthijs. 1670. D'Indiaensche Tyfferboom: uyt-tijifferende verscheyden heylsame, nuttige en ziel bedenckende rymen. Amsterdam: Abraham van den Burgh.

De Graaf, Hermanus Johannes. 1956. De vijf gezantschapreizen van Rijklof van Goens naar het hof van Mataram 1648-1654. 's-Gravenhage: Nijhoff.

De Graaff, Nicolaus. 1701. Reisen van Nicolaus de Graaff, na de vier gedeeltens des werelds [...]. Tot Hoorn: Feyken.

De Marre, Jan Harmenz. 1740. Batavia, begrepen in zes boeken. Amsteldam: Adriaan Wor dan de Erve G. onder de Linden.

Maier, Henk. 1996. "Indische Literatuur; Bezinningen op een definitie", di dalam: Theo L. D'haen (red.), Weer-werk; Schrijven en terugschrijven koloniale en postkoloniale literaturen, hlm. 14-30. Leiden: Vakgroep Talen en Culturen van Zuidoost-Azië en Oceanië. (Semaian 15).

Nieuwenhuys, Rob. 1978. Oost-Indische spiegel; Wat Nederlandse schrijvers en dichters over Indonesië hebben geschreven vanaf der eerste jaren der Compagnie tot op heden. Cetakan ketiga. Amsterdam: Querido. (Cetakan pertama tahun 1972).

Paasman, Bert. 1991. "Lof van Oost-Indiën; Liedjes uit de VOC-tijd", Indische Letteren 6-1 (Maret): 1-17.

Paasman, Bert. 1999. “Grenzen en grenscorrecties in de Indisch-Nederlandse literatuur", Indische letteren 14-2 (Juni): 66-72.

Paasman, Bert. 2002 "De Indisch-Nederlandse literatuur uit de VOC-tijd", di dalam: Theo L. D'haen (red.), Europa buitengaats; Koloniale en postkoloniale literaturen in Europese talen, hlm. 33-97. Amsterdam: Bakker. 2 jilid.

Paasman, Bert. 2005. 'De muze buitengaats: een heroriëntatie op de IndischNederlandse dichtkunst', Indische letteren 20-3 (September): 163-195.

Rumphius, Georgius Everhardus. 1705. D'Amboinsche Rariteitkamer. Amsterdam: François Halma.

Rumphius, Georgius Everhardus. 1741-50. Het Amboinsche kruid-boek, [...]. Amsterdam: François Changuion, Jan Catuffe. 6 jilid.

Steendam, Jacob. 1671. "Danck-offer"; Zeede-sangen voor Batavische jonkheyt; behelsense verscheyden benedenlijke, en stichtelijke stoffen. Batavia: Pieter Walberger. 
Valentijn, François. 1724-26. Oud en Nieuw Oost-Indiën, [...]. Dordrecht: Joannes van Braam; Amsterdam: Gerard onder de Linden.

Van Goens, Rijklof. 1666. Javaense Reyse. Dordrecht: V. Caimax.

Van Haren, W. 1742. Gedicht op den moord gepleegd aan de Chineesen te Batavia den IX Octob. Anno 1740. 's-Gravenhage: Isaac de Beauregard.

Van Heemskerck, Johan. 1982. Inleydinghe tot het ontwerp van een Batavische arcadia. P.E.L. Verkuyl (red.) Fell. 1. Deventer: Sub Rosa. (Cetakan pertama 1678).

Van Hogendorp, Willem. 1780. Kraspoekol, of de droevige gevolgen van eene te verre gaande strengheid, jegens de slaaven; Zedekundige vertelling. Batavia: Lodewyk Dominicus.

Van Hogendorp, W. 1921. Sophronisba of de gelukkige moeder door de inëntinge van haare dochters: Europeesche geschiedenis ter leezinge voorgesteld aan de moeders van Batavia. Rijswijk: Javasche Boekhandel en Drukkerij. (A reprint of the Batavia edition of 1779; Batavia: Lodewijk Dominicus). 